\title{
Role of Cooperatives in Rural Development, the Case of South Nations Nationalities and People Region, Ethiopia
}

\author{
Nuredin Mohammed ${ }^{1}$, Byeong Wan Lee ${ }^{2}$ \\ ${ }^{1}$ Ethiopian Agricultural Transformation Agency, SNNPR, Ethiopia \\ ${ }^{2}$ Park Chung Hee School of Policy and Saemaul of Yeungnam University, Gyeongsan, South Korea
}

Email address:

ynmk60@yahoo.com (N. Mohammed),ynmk79@gmail.com (N. Mohammed)

\section{To cite this article:}

Nuredin Mohammed, Byeong Wan Lee. Role of Cooperatives in Rural Development, the Case of South Nations Nationalities and People Region, Ethiopia. Science Journal of Business and Management. Vol. 3, No. 4, 2015, pp. 102-108. doi: 10.11648/j.sjbm.20150304.12

\begin{abstract}
For small land-holding, developing and agricultural based economic countries like Ethiopia, cooperative type of business is recommended as a solution to promote income distribution, reduce poverty and vulnerability, and improve quality of life and social welfare. Ethiopia is a second largest populace country in Africa and has nine regions and two city administrations. South Nations Nationalities and Peoples Region (SNNPR) state is third populace and most densely populated region in Ethiopia. Most of the farmers' in this region have small plot of lands for their living, farming and raising animals. It is obvious that such smallholder farmers are characterized by producing small amount of produce. They might bring small portion of their product to market, and the earnings might goes to cover their routine expenditure and might save the remaining for next farming season. Having this clear fact in to consideration, Since 1960s, the government of Ethiopia is promoting the significance of cooperatives as an organization that could enhance the development of small scale-farmers and other communities. Unlike other regions, SNNPR is the pioneer for starting cooperatives type of business; cooperatives are still flourishing in the region. Cooperatives are expected to serve farmers by providing agricultural inputs, output marketing and mobilizing savings and providing credit services to their members. The objective of this paper is to show role of cooperatives in rural development the case of South Nations Nationalities and Peoples Region. Until June 2011, in SNNPR state there were about 8872 primary cooperatives, 44 Cooperative Unions and One Regional Farmers Cooperative federation are established. These cooperatives have a membership of male $693,898(77 \%)$ and female $209,861(23 \%)$ totally 903,759 . This is about $30.3 \%$ from the total households of the region. Despite early establishment of cooperatives across the region and country wide, cooperatives couldn't flourish as expected. Past attitude (ideology), lack of committed leadership, lack of good governance (management), lack of working capital, attitude and practice of corruption, lack of knowledge and skill, lack in provision and utilization of improved technology, weak vertical and horizontal linkage within and among cooperatives, lack and inappropriate support from government and other stakeholders.
\end{abstract}

Keywords: Cooperative, Agricultural Inputs, Marketing, Saving and Credit

\section{Introductions}

The economy of Ethiopia is largely based on Agriculture, accounting over $41 \%$ of gross domestic product (GDP), $83.9 \%$ of exports, and $90 \%$ of total employment. Nearly $83 \%$ or $(75.6$ million) of the population is living in rural areas. Many other economic activities are be dependent onagriculture, including marketing, processing, and export of agricultural products. In September 2010, the first time Ethiopia has publicly announced a five year Growth and Transformation Plan (GTP) $2010 / 11$ to $2014 / 15$. The principal development agenda of GTP is to sustain rapid and broad-based growth path witnessed during the past years and eventually end poverty. As determined by GTP, Agricultural sector will remain the main engine for its success and at the endof a plan year the industry sector is expected to take the leading position. Accordingly Cooperative promotion is one of the target areas in agricultural and rural development strategy as well as in GTP I. In view of that, there are three major tasks that GTP clearly stated for cooperatives. First, provision of improved agricultural technologies to increase production and productivity, Second, improved agricultural marketing (output marketing) system; and third, financing (saving, credit and banking).

Modern cooperative movement started 160 years ago in the world, about 60 and 50 years correspondingly in Africa and Ethiopia. According to Federal Cooperative Agency of Ethiopia, until 2011, 43,255 different types of primary 
cooperatives were established with a membership of male $5,153,271$ and female $1,413,423$ totally $6,566,694$. These member households with their family's account about $32,833,470$, i.e.almost $37 \%$ of the total population of a country is directly lean on cooperatives. Moreover 278 cooperative unions and 4 regional cooperative farmers' federations were established. Likewise until 2011, in SNNPR there were about 8,872 primary cooperatives, 44 Cooperative Unions and One Regional Farmers Cooperative federation areestablished. These cooperatives have beena membership of male 693,898 (77\%) and female $209,861(23 \%)$ totally 903,759 . This is about $30.3 \%$ from the total households of the region. Cooperatives, in a particular agricultural cooperatives, Rural Saving and Credit Cooperatives (RUSACCO), and Consumer cooperatives do played a major role in production, primary processing and marketing of agricultural products; mobilizing saving and providing credit; and provision of basic consumer goods and services for their members and the surrounding.

The general objective of cooperative is to promote the economic interest and general welfare of members in accordance with cooperative principles and values. Despite early establishment of cooperatives across the region and country, cooperatives couldn't flourish as expected. Past attitude (ideology), lack of committed leadership, lack of good governance (management), lack of working capital, attitude and practice of corruption, lack of knowledge and skill, lack in provision and utilization of improved technology, weak vertical and horizontal linkage within and among cooperatives, lack and inappropriate support from government and other stakeholders.

This paper gives emphasis to cooperative movement, development and challenges in SNNPR. In this region there was no region specific studies were carried out in cooperatives sector before. Therefore, the objective of this paper is to over view the cooperative movement, development and challenges in SNNPR and finally to draw some conclusions on major problems. The paper use secondary data as a main source which include qualitative and quantitative descriptions. The remainder of the paper is organized as follows. Chapter two gives a background and importance of cooperatives. Chapter three over views the cooperative movement and its major achievements in SNNPR. Chapter four discuss the challenges at different level that cooperatives encountered. Chapter five gives summaries and conclusion.

\subsection{Cooperatives Definition, Principles and Values of Cooperatives}

The history of cooperation is directly related with human being, because, human being traditionally cooperate each other in day to day life to overcome their immediate problems and also to share their feelings. Representative body for cooperatives, the International Cooperative Alliance (ICA) define cooperative in 1995, as "An autonomous association of persons united voluntarily to meet their common economic, social and cultural needs and aspirations through a jointly owned and democratically controlled enterprise."

U.S. Agency for international Development, (1985) explained that, Cooperative forms of social and economic organizations exist throughout the world, engendered and molded by often quite dissimilar social, economic and political traditions. No single definition of "cooperative" would be adequate to describe the diverse activities that have been labeled "cooperative." But it is possible to identify certain common characteristics of cooperative organizations.

\subsection{Importance of Cooperatives}

Classical and neoclassical theorists allocate important roles to cooperative associations: (1) Cooperatives occupy niches of market development and integrate them into the overall system of capitalism. (2) Cooperatives change the preferences, habits and characters of their members and thereby trigger economic development and social reform. (3) Cooperatives manage to exploit local knowledge as an otherwise costly production factor. (4) Cooperatives ease the pooling of resources and the buildup of power. (5) Cooperatives establish a class of cooperative entrepreneurs and allow this class to remain independent (Markus H. 2005).

Furthermore cooperatives and particularly agricultural cooperatives do play a major role in production, primary processing and marketing of agricultural and livestock commodities. The justification for cooperative arises from their potential in maximization of profits, harnessing various skills with members, enhancing advocacy and bargaining power, enhancing financial accessibility, boosting social capital, promoting investment, providing educational opportunities, improving market access and contributing to poverty reduction (Paul G. and Isaac K.). Smallholder farmers gain big benefits from agricultural cooperatives including bargaining power and resource sharing that lead to food security and poverty reduction for millions, the UN Food and Agriculture Organization (FAO). Empowered by being a part of a larger group, smallholder farmers can negotiate better terms in contract farming and lower prices for agricultural inputs like seeds, fertilizer and equipment. In addition, cooperatives offer prospects that smallholder farmers would not be able to achieve individually such as helping them to secure land rights and better market opportunities (FAO, 2011).

\subsection{Cooperatives for Rural Development}

Agriculture, including farming, forestry, fisheries and livestock, is the main source of employment and income in rural areas, where the majority of the world's poor and hungry people live. Agricultural cooperatives play an important role in supporting men and women small agricultural producers and marginalized groups by creating sustainable rural employment. Producer cooperatives offer men and women smallholders market opportunities, and provide them with services such as better training in natural resource management, and better access to information, technologies, innovations and extension services (FAO, 2011).

Cooperatives have played a major role in the agricultural industries of all developed countries and many developing 
countries for well over a century. They have been important in farmsupply, providing fertilizer and other inputs, and product marketing including transport, storage and processing (Yue Zhou, 2003). Different cooperatives are playing vital roles around the globe. For example, cooperatives control about $80 \%$ of dairy production, while in California most of the specialty crop producers are organized in cooperatives. In Colombia, the National Federation of Coffee Growers provides production and marketing services to 500,000 coffee growers. It contributes to the National Coffee Fund, which finances research and extension for coffee-growing communities. In 2005, the Indian Dairy Cooperatives, with 12.3 million members, accounted for 22 $\%$ of the milk produced in India. $60 \%$ of members are landless or have very small plots of land. Women make up 25 $\%$ of the membership. In Brazil, cooperatives are responsible for $40 \%$ of the agricultural GDP and $6 \%$ of total agribusiness exports.

However, cooperatives around the world over are in a state of instability. In almost all parts of the world, cooperatives face in one or another way facing the same challenges. Such as past attitude (ideology), lack of committed leadership, lack of good governance (management), lack of working capital, attitude and practice of corruption, lack of knowledge and skill, lack in provision and utilization of improved technology, weak vertical and horizontal linkage within and among cooperatives, lack and inappropriate support from government and other stakeholders.

\section{Cooperatives Movement in SNNPR Ethiopia}

SNNPR has a long history of cooperative movementin Ethiopia, which has been characterized by strong growth, thus making a significant contribution to the overall economy of the region and the country as well. Like the federal government, regional government is also recognized cooperatives as a major contributor to the rural and agricultural development. Different types of cooperatives are established in every corner of the region. From the total population of the region 17 million, nearly $30.3 \%$ of the people participated and benefited directly or indirectly from cooperatives type of business.

In SNNPR Cooperative movement started half a century ago. Some legends thought that this region is the pioneer in establishing the first cooperative in Ethiopia. Officially cooperative movement started during Emperor Haile Selassie's regime (1930-1975), the movement was became bubbled during the regime of Derg (1974-1991). The Derg regime considered cooperatives as a mass movement that could ensure equitable mobilization and distribution of resources. They were thus viewed as instruments for planning and implementation of socialist policies/ ideology of the regime. Many cooperatives were organized in SNNPR region and the entire country to accomplish this objective. During these periods farmers were forced to pull their produces to the local multipurpose cooperatives and then price of their produce was determined by government. These cooperatives had been served not for their members, rather for political sustainability of the military government. Fortunately, these forcefully organized cooperatives were devastated by their own members, when the military regime abolished by the current Ethiopian People's Revolutionary Front (EPRDF) in 1991. The current government highly recognized cooperative as a major contributor for agricultural and rural development.

SNNPR government also gave due attention for the establishment of cooperatives. Accordingly the region formulated cooperative proclamation along with federal government, also organizational structure to promote cooperatives established up to village level. Due to this, until June 2011, about 8,872 (out of which 2,420 are saving and credit cooperatives) primary cooperatives were established with a membership of male 693,898 (76.8\%), female 209,861 (23.2\%) totally 903,759 . In addition, 44 cooperative unions were organized, comprising about 1,003 primary cooperatives as members. Also 13 cooperative unions and 2 primary cooperatives together established regional farmer's cooperative federation. Overall, dominantly these cooperatives are engaged in agricultural input-output marketing, saving and creditcooperatives.

These cooperatives are tried to providevarious services to its members like; provision of agricultural inputs such as improved seeds, fertilizer, agro-chemicals, farm tools and equipment's; output marketing both localas well as international market; market information, banking services (saving after harvesting time, credit during farm season), capacity building training, provision of basic consumable goods, employment opportunities, education for their children, social security, building infrastructure such as school, health, water, rural road; housing, environmental protection, electric power line construction and so on. Meanwhile increase foreign currency for a country, spillover effect for the surrounding people by creating job, infrastructure, market, and so on.

Unlike any other similar sector in the country, Bureau of Marketing and Cooperative has made very crucial tasks in cooperatives movement. The first one is collection of basic data from all cooperatives across the region; Second, rating all cooperatives based on minimum standard criteria. Critical points under minimum criteria are management and organizational efficiency, member's participation and benefit, capital, input provision and distribution, marketing system and service delivery, accounting and auditing, profitability and its role in environmental protection. Third, detailed sample study has been conducted from 85 primary cooperatives which are engaged in 17 types of businesses; 16 secondary (unions) cooperatives which are also engaged in 7 types of business; and in one regional farmer's cooperative federation.

Up untilrecent, it was difficult to get confidential information or data about the development status of cooperatives in a region, any plan and technical support was relied on projection and approximates. The reasons behind this important commencement was; first, to classify active and 
inactive cooperatives in order to prepare accurate plan, to provide effective implementation support, to carry out the right performance evaluation; second to identify potential challenges and problems that obstruct cooperatives development; third, to point out possible solutions in order to make the ground more suitable to promote cooperatives.

According to collected data, result of minimum standard and study report, few cooperatives were found in a good condition, some areat anintermediate level and most of the cooperatives were not found in a good condition. As we discussed above, now the bureau has got full information about the status of cooperatives and favorable environmentis created to give proper technical assistance for cooperatives based on its level, unlike collective and inefficient assistance before.

Farmers in rural areas faced difficulties accessing quality inputs. While the selling price for crops may be higher, farmers also have to cause in the variable cost of buying seeds and fertilizer before deciding to expand their production. Access to loans to buy these inputs can also be a problem. Even when all these conditions are encouraging, many small producers face still other obstacles - such as lack of transport and other infrastructure to bring their product to local markets. Therefore, in the process of solving such bottlenecks, few cooperatives unions were doing very excellent, exemplary activities, and benefiting its members as well as others across the region, and also pointing out their finger in the economic development of the region and the country as well.

Sidama Farmers Coffee Cooperative Union (SFCCU) and Yirgacheffe Farmers Coffee Cooperative Union (YFCCU) are an exemplary cooperative unions form agricultural cooperative unions. Both unions are popular in the world coffee market by providing extra ordinary garden Arabicacoffee. They are found in Sidama and Gedeo zone respectively. Theseunions are collecting coffee from member primary cooperatives at village level, and after processing sold out in the world market. During harvesting time they provide loanto member primary cooperativesand for some of its member primary cooperatives, the unions guaranteedto the bank for loan. Both unions are thoroughly penetrated world market and competing by its well noun brands; its market destination is North America, Europe and Asia. Yearly they are maximizing its profit, based on member's participation and amount of share (equity) from the total profit $70 \%$ as a dividend belongs to member primary cooperatives. Primary cooperative are also distributed $70 \%$ to its individual member farmers; this process of allocating margin carried out based on member's participation and amount of share. Through this kind of continues process individual farmer's income is increasing from time to time. Because of this, farmers are started to send their children to school, improving their way of living (housing, food, cloth, and healthcare).

On top of this, through these cooperative unionsindividual farmers are benefiting from Fair Trade premium. Fair Trade is a global trade model and certification allows shoppers to quickly identify products that were produced in an ethical manner. For farmers and workers in developing countries, Fair
Trade offers better prices, improved terms of trade, and the business skills necessary to produce high-quality products that can compete in the global marketplace. For that reason on behalf of individual farmers SFCCU and YFCCU are received premium. This fund is specifically designed for social, economic and environmental development projects in member farmer's areas. Through this, both unions based on farmer's interest built rural roads, bridges, water points, electric line, schools and facilities.

Like SFCCU and YFCCU of agricultural cooperatives unions; Netsanet Fana Saving and Credit Cooperative Union (NFSACCU) is the one and an exemplary as well as role model to other similar cooperatives in the region and country level. It is found in Meskan Woreda (District) Butajira City Administration, Gurage Zone, established in 2004. Its initial member primary cooperatives were 10 , individual members 965(all of them were females), capital US\$15,577. After seven years of establishment i.e. in June 2011 its members primary cooperatives became 80 , its saving dramatically increased to US\$382,224. In addition to saving, credit is the main service of the union. Therefore, the amount of credit to primary cooperatives increased by nearly three folds i.e. from US $\$ 27,714$ to US\$70,760, similarly credit to individual members increased from US\$114 in to US\$4,166, and total asset US\$ 269,496. Unlike any other cooperatives unions, female participation is the key issue in Netsanet Fana Saving and Credit Union for that reason female's participationin leadership was $65 \%$ at union level and $92 \%$ at in its member'sprimary cooperatives.

Furthermore, in order to give appropriate services at the right time and places the union opened branch offices nearby its members. Since it is working in finance there has been serious risk, so the opening of branch office was very significant. Traditionally loan collection trend was very poor at country level, but such trend has no any ground here in NFSACCU. Loan collection performance was almost $99 \%$ and no non-performing loan at all and the other important fact was its implementation of modern accounting system. As we discussed the major objective of cooperative is improving the livelihood of the people or its members. Therefore, about 200 members of the union have changed their traditional hut house to modern type of iron made houses, about 8 members have been created additional income generating mechanism by purchasing three wheel taxi so called Bajaj, 21 members have boughtsinger sewingmachines and 71 members engaged in different retail trading and beyond this they send their children to school. In general most households have increased their assets, particularly livestock, bought new farming equipment to further increase productivity and some households said that their livelihoods have been 'transformed'.

As we thrash out above, the other most severe problem in rural areas was and also is provision of agricultural inputs for production and productivity with appropriate quality, quantity, time, price and place. In this regard Edget Seed Multiplication and Marketing Cooperative Union (ESMMCU) lead the way in the region and the entire country as well. This union is established in 2008, comprising 12 primary cooperatives as 
member to work within 6 districts of Gurage and Silte Zone. Since seed multiplication process needs technical knowhow, skill and close supervision, expertise from research center and office of agricultural have been doing in a great collaboration with the union. The main tasks of union is provision of basic seeds to its members from research Centre, provision of fertilizer, agro-chemicals, and other necessary materials with close monitoring and technical support. Then after harvesting collecting seeds, examining seed germination and purity test in its owned seed laboratory, finally packed and distributed to other farmers within zones, and also to other zones within the regions. Therefore, within three years of establishment, the union could provide more than 600tones of improved wheat and Teff improved seeds to the farmers.

\section{Major Challenges of Cooperatives}

Despite success stories of some or few cooperatives, there were also critical challenges in cooperatives sectors. According to sample study and minim standard measurement; initially the bureau believed that there were about 9,254 primary cooperatives, but after collecting the data, about 8,872 primary cooperatives were in place and the rest 382 primary cooperatives either initially were not in place or tear down due to lack of close assistance in its incubation period. Meanwhile, of 8872 primary cooperatives $63.4 \%$ (5625) were scored below minimum standard points $(<50)$, and about 1041 primary cooperatives scored below 10 points out of 100 .

Likewise, sample study was also identifiedcritical points. This was conducted in 86 primary cooperatives and 16 cooperative unions including regional farmer's federation. The finding was, 62 out of 86primary cooperatives couldn't follow the rule and regulation of their own by-laws and cooperative principles. I.e. traditionally executingtheir day to day activities without irrespective of legal frame work, most of them couldn't utilize full legal documents for their business transactions; and, auditing and accounting documents were not fulfilled, even some had none of it. Additionally 32 out of 86 primary cooperatives couldn't get auditing services at all. Member's participation waspoor both in planning, implementation, marketing and saving; hence most of them were dangerously abused by elected leaders. The abasements are mainly related to corruption and mismanagement such as, gross mismanagement by officials; failure to hold elections, theft of cooperative resources, refusal of management committee members to vacate after members voted for this dismissal; conflict of interest among cooperative officials; lack or absence of litigation on corrupted persons, and unauthorized cooperative investments. Moreover Women participation in leadership was found only in 24 out of 86 primary cooperatives and the same thing happened in unions and federation 3 out of 17 . Which implied how the degree of attention to participate and empower women was weak?

In addition, the other challenges is lack of awareness of their business potential among governments and the general public, also often leads to mischaracterization of their interests. Engendered by none or minimal relationship between members and management and self-perpetuating attitude of board members. There were also weak relationship and coordination within and between government and none government organization working on cooperative. verall in sample study and minim standard measurement, dentified challenges are generally categorized as a follows:

\subsection{Internal Challenges}

These are the challenges emanated from the cooperatives (primary up to federation level) embers, managers, managements and Board members. Mainly: - Weak linkage between individual members vs. primary cooperatives; Primary with cooperative unions; and Unions with federation. ack of awareness, knowledge and skill on significance and impact of cooperatives, cooperative management, planning, leadership, and marketing; Managerial problems are a problems related to participation, transparency, loyalty, good governance, efficiency, motivation; Ethical problems are related to, managers and Board members were reluctant in fighting corruption and they were also part of, Weak participation of members and unwillingness of increasing their equity; high loan demand but unwilling to refund on time; lack and shortage of warehouse; credit, transport; marketing information; weak trade linkage, and poor rural infrastructure like road, energy, and agricultural processing. Likewise Over dependency on government and NGO's, weak documentation, and less women participation as membership and leadership were also critical challenges. Therefore, these hindered cooperative development or put in stagnation or in development trap.

\subsection{External Challenges}

These challenges were belongs to government structures, which was established to support cooperative sector. As we seen before, regional government gave much attention to the development of cooperative particularly for rural areas. Besides appointing officials at each level, government also hired 5000 expertise across the region. Different capacity building on-job and off-job training was conducted locally and at regional level. Beyond this most expertise up graded their educational status in local colleges, some in national universities and few in abroad.

However, despite these massive efforts, the required development in cooperative sector couldn't achieve. Because, the problem was mainlyrelied on weak leadership and supervision; weak and irregular technical assistance; expertise lack knowledge and skill, by the tie of establishing cooperatives expertise intend to focus in number of cooperatives rather than giving outstanding attention for quality; Shortage of efficient, qualified and committed leaders and expertise; weak documentation and information; weak horizontal and vertical relation, and coordination. Moreover unstable structure would result in high staff turnover; lack of regular follow up, attitude and practice of corruption, as the same time reluctant to fight corruption in court; unfair resource allocation to cooperative promotion sector 
particularly at district level which was reflected in shortage of human resources, budget, and logistics; weak public relation activities, and in some case interference also a big challenges. Similarly weak coordination with other sectors majorly like Agriculture, Trade and Industry, Justice, Local municipalities, Women Children and Youth, and Financial institutions, in cooperative development the contribution of these sectors is very crucial.

\section{Conclusion and Recommendation}

The role of cooperative to economic development in developed, developing and under developed countries are very immense. As we discussed, their role in rural areasparticularly for those marginalized people are crucial. Because cooperatives recognized by $\mathrm{UN}$ and other international organization, as a solution for equality, poverty reduction, building social capital, improving marketing and financing system, empowering producers and women. Therefore, the attention given by different countries and organizations are important and implies their intention as the same time their commitment for sustainable development.

SNNPR's population almost $88 \%$ (12-13million) is living in rural areas, majority of the people have small plots of land and density of population is also highest in the country. As we understand from the above demographic data, the economy of the region heavily relied on agriculture. Agricultural development needs different inputs to increase production and productivities. Hence, obviously the significance of cooperatives in the region came to realities. So due to these facts regional government not only gave attention, but also empowers the sector by upgrading its status. These all efforts are ultimately to strength and capacitate cooperatives in order to provide proper goods and services to its members as well as to contribute their role in regional development. One big witness was unlike other regions, this region has allocated budget and other necessary resources to collect basic data, measuring by minimum standard as well as conducting sample studies. Of course these might be one of the responsibilitiesof government, but this couldn't happen without such committed leadership.

In country's 'at the same time in regional GTP, agricultural input provision, output marketing and saving mobilization are major tasks of cooperative sector. But these could not be possible with the current pace of cooperative performance. So the sector has to clean up from its in-depth and complex problems. Correspondingly concerned leaders at each level should take the lion share in this regard. It is clear and impossible to solve all tribulations overnight.

Therefore, in order to solve such problems Regional government and cooperative promotion sector has to design regional clear set cooperative development policy and Cooperative Development Strategy. This policy and strategy presents the way forward for cooperative development in the region. It should encourage cooperatives to engage in small agro-processing industries based on their potential resources, this will help in creating employment, better price for value addition, earning as the same time saving foreign currency, technology transformation; capacity building; establishment of regional cooperative fund or design mechanism the way how cooperative get loan/credit for their business, constructing warehouses. Otherwise how one can expect more outcomes from this sector with their own limited resource? The new strategy should give proper and on time response for this.

Additionally until now there is no extension system, so the preparation of such system should get priority in the strategy; the other important point is establishment of cooperatives research and development; yet again this strategy has to address the redundant or duplication of efforts between government sectors and also in between primary cooperatives, unions and federation, as the same time has to address potential way of coordination. Duplication of efforts and coordination failure in government sectors should be well-thought-out. Beyond these, inter and intra problems in cooperatives should also be considered. However, this paper couldn't touch all the critical points on cooperatives, so we kindly recommend further studies on this sector.

Therefore, if the above mentioned and other related issues are undoubtedly addressed in the Regional Cooperative Strategy, cooperatives definitely achieve their objective in line with the realization of regional GTP.

\section{Acknowledgements}

First of all, I would like to thank my Lord Allah for being with me in all aspects. I am also grateful to thank Ato Sani Redi, Ato Usman Surur, officials and expertise of Bureau of Marketing and Cooperative.

I would like to express my gratitude to co-author Professor Byeong Wan Lee for the useful comments, remarks and engagement through the learning process of this paper. Furthermore I would like to thank Professor Han, Dong Geun Head department of Public Policy and Leadership for his guidance and support. Also I gratefully acknowledge Park Chung Hee School of Policy and Saemaul for giving scholarship and for its support in the undertaking of this paper. I would like to express my special gratitude and thanks to my families, friends (Zalla), Mohammed Welebe (Kore) and Dr. Demeke Atlaw for their great contribution in the completion.

\section{References}

[1] Ann Hoyt. And Then There were Seven: Cooperative Principles Updated. Athens, University of Wisconsin, 1996.

[2] Bezabih Emana. Cooperative: a path to economic and social empowerment in Ethiopia. Dare Salam, Coop ${ }^{\text {AFRICA }}$ working paper No.9, ILO 2009.

[3] Bureau of Marketing and Cooperative Ethiopia."Annual Report.” Hawassa, SNNPR Ethiopia, 2011.

[4] FAO. Agricultural Cooperatives are Key to reduce hunger and poverty. 2011 
[5] FAO. Agricultural Cooperatives: Key To Feeding The World. World Food Day2012,

[6] Michael Gertler. Rural Cooperatives and Sustainable Development. Canada, University of Saskatchewan, 2001.

[7] Markus H.A governance Perspective on the role of Cooperative in Rural Development., 2005. Laidlaw, A.F (1974): The Cooperative Sector, Columbia: University of Missouri

[8] Paul G. and Isaac K. Evolution, Growth and Decline of the Cooperative Sector. Nairobi, Centerfor Governance and
Development.

[9] USAID Policy Paper: Cooperative Policy. Washington D.C. 20523, Bureau for Program and Policy Coordination, 1985.

[10] World Council of Credit Unions."Statistical Report." Washington DC, USA, 2011.

[11] Zhang-Y. Z. China's Experience with Agricultural Cooperatives in the era of Economic Reform. Asian Agribusiness Research Centre, The University of Sydney, Orange NSW 2800, 2004. 